\title{
Assessment of water quality of Ogbese River in Ovia North-East Local Government Area of Edo State, Nigeria
}

\author{
C.L. ORJIEKWE ${ }^{1 *}$, D.T. DUMO ${ }^{1}$ and N.B. CHINEDU ${ }^{2}$ \\ ${ }^{l}$ Department of Chemical Sciences, College of Natural and Applied Sciences, Igbinedion University, Okada, \\ PMB 0006, Benin City, Edo State, Nigeria. \\ ${ }^{2}$ Department of Industrial Chemistry, College of Natural \& Applied Sciences, Renaissance University, \\ Ugbawka, Enugu State, Nigeria. \\ *Corresponding author, E-mail: chikeorjiekwe@yahoo.com ; Tel.: +234 8035068631
}

\begin{abstract}
The pollution of Ogbese River in Ovia North-East L.G.A. of Edo State, Nigeria was studied. Parameters like $\mathrm{pH}$, temperature, electrical conductivity, colour, odour, chlorides, nitrates, phosphates and heavy metal ions such as lead, chromium, zinc etc, were analyzed. Also various techniques such as titrimetric methods, atomic absorption spectrophotometry were employed in the determination of these ions. The results show that most of the pollution indices of the water samples analyzed indicate that the Ogbese River water falls within the acceptable range for natural waters according to the World Health Organisation (WHO, 2006) standards. However, the Ogbese River water falls short of potable water on account of high presence of coliforms bacteria found in the river water. Defaecations of human, wild animals and runoffs from agricultural farmlands are believed to be the source of the coliforms bacteria.

(c) 2013 International Formulae Group. All rights reserved.
\end{abstract}

Keywords: Water pollution, environment, water analysis.

\section{INTRODUCTION}

The threats from pollutants in water supplies have been under searchlight for sometime now because of the various adverse effects of the pollutants (Ogunlaja et al., 2007; Yadav et al., 2011). The effluents from industries, domestic wastes and sewage from homes, agricultural wastes contain contaminants which end up as run offs into rivers and pollutes the water. Such contaminants include mercury, chromium, lead, arsenic, copper, phosphates, nitrates etc (Isreal, 2000; Kazuo, 2001; Wang, 2003; Demirel, 2004; Orjiekwe et al., 2006).
One major problem in developing countries is shortage of adequate potable water, especially in the rural communities that depend on streams, rivers, ponds and streams as chief source of drinking water. Anthropogenic factors have been identified as major source of pollution of water bodies (Liven, 2005; Phiri, 2005; Raccine, 2005; Kumar et al., 2013).

Nigeria, as a major producer of oil in the world, has been suffering from severe environmental pollution, especially in the Niger Delta region where virtually all her oil production takes place. Concerns over the biological effects of increasing oil spillage on 
rivers, estuaries, fish ponds and other water bodies are mounting. Effective means of cleaning-up these spills have been sought after in order to reduce some of the harmful effects of spillage in the environment.

In one of our previous paper, we reported on the water quality index assessment of Evebonede and Ovia Rivers in Ovia North-East Local Government Area of Edo State, Nigeria (Orjiekwe et al., 2006) Figures 1 and 2. Most pollution indices measured are far above the limits approved by WHO for clean, safe and potable water. Moreover, pathogenic organisms such as Coliforms, Pseudomonas, Vibro, Samonella and Shigella spp. were confirmed present in the river waters. This has obvious great health implications for the rural dwellers.

In the present study, efforts have been made to provide an insight into the concentration levels of contaminants in Ogbese River which serve as major source of water supply to the neighbouring rural communities. The study will be useful to governments at local, state and national levels as well as to other agencies concerned with environmental health and well being of rural dwellers.

\section{MATERIALS AND METHODS}

The physicochemical parameters and microbiological studies were determined by employing the methods reported extensively in one of our previous papers (Orjiekwe et. al. 2006). Briefly, the measurements include:

\section{Temperature}

Measurements were made with a Celsius thermometer at the sampling points by immersing the thermometer directly in the river for about a minute, which was significant enough to permit constant reading. The temperatures were recorded to the nearest $0.5{ }^{\circ} \mathrm{C}$.

\section{pH measurements}

A battery powered $\mathrm{pH}$ meter was used and the $\mathrm{pH}$ values were reported to the nearest $0.1 \mathrm{pH}$ unit.

\section{Electrical conductivity}

The electrical conductivities of the river water samples were recorded at room temperature $\left(25 \pm 0.1{ }^{\circ} \mathrm{C}\right)$ on a WTW LBR conductivity bridge with a cell constant of 1.63 .

\section{Total suspended solids (TSS)}

A glass fiber filter paper was dried to a constant weight in an oven at $103-105{ }^{\circ} \mathrm{C}$. The glass fiber filter paper was affixed to a Gooch funnel and suction flask connected to vacuum pump. $250 \mathrm{ml}$ of the river water samples were withdrawn with pipette into the filtration setup and filtered using vacuum pump. The glass fiber filter paper was carefully removed and again dried to a constant weight. The TSS is measured as the difference in weight of the glass fiber filter paper before and after the filtration using the formula:

TSS $(\mathrm{mg} / \mathrm{L})=\frac{\mathrm{mg} \text { of suspended solids } \mathrm{x} 1000}{\mathrm{ml} \text { of }}$ $\mathrm{ml}$ of sample water used

\section{Total dissolved solids (TDS)}

The TDS was obtained by the difference between the total solids (TS) and the TSS.

TDS $=$ TS - TSS

Prior to TS determination, a clean evaporating dish was dried in the oven at 103 $-105{ }^{\circ} \mathrm{C}$ to a constant weight. $100 \mathrm{ml}$ of the river water sample was withdrawn after thorough mixing into the evapourating dish and subsequently evapourated to dryness on a steam bath at $103-105{ }^{\circ} \mathrm{C}$ to a constant weight. The difference in weight of the dish is noted. The TS is calculated using the formula:

$$
\mathrm{TS}(\mathrm{mg} / \mathrm{L})=\frac{\mathrm{mg} \text { of total solids } \mathrm{x} 1000}{\mathrm{ml} \text { of sample water used }}
$$

\section{Metal ions}

The metal ions $\mathrm{Cd}^{2+}, \mathrm{Cr}^{3+}, \mathrm{Cu}^{2+}, \mathrm{Pb}^{2+}$, $\mathrm{Mn}^{2+}, \mathrm{Hg}^{2+}, \mathrm{K}^{+}, \mathrm{Na}^{+}, \mathrm{Zn}^{2+}$ and $\mathrm{As}^{3+}$ were determined using atomic absorption spectrophotometric method using appropriate hollow cathode lamp at the stipulated wavelengths in the Table 1 below. 
Colorimetric method was employed in the determination of $\mathrm{Al}^{3+}$ and $\mathrm{Fe}^{3+}$ at the stipulated wavelengths. In the determination of $\mathrm{Al}^{3+}$, the Eriochrome cyanide method was employed to develop the colour and the absorbance was subsequently measured on a $\mathrm{HACH}$ spectrophotometer at $535 \mathrm{~nm}$. The photometric phenanthroline was used in the determination of iron. The ferrous iron was chelated with 1, 10-phenanthroline to form an orange-red complex and thereafter the absorbance was measured at $510 \mathrm{~nm}$ using a HACH spectrophotometer.

Titremetric methods was employed in the determination of $\mathrm{Ca}^{2+}$ and $\mathrm{Mg}^{2+}$ at controlled $\mathrm{pH}$ values. Initially, the river water samples were titrated with EDTA to determine the total content of $\mathrm{Ca}^{2+}$ and $\mathrm{Mg}^{2+}$ ions using Eriochrome black as indicator. For the determination of $\mathrm{Mg}^{2+}$ ions alone, the $\mathrm{Ca}^{2+}$ ions was first precipitated as its oxalate and removed by filtration. Thereafter, the river water samples were titrated with EDTA using Eriochrome Black indicator. The solution changed from wine red to blue at the end point.

\section{Chlorides}

In the determination of nitrate, the mercuric nitrate method was used. Chloride ions reacted with mercuric ions to form a highly stable complex, which was titrated with a standard solution of mercuric salt. The end point was determined by a diphenylcarbazone indicator, which formed a blue violet complex with an excess of mercuric ions.

\section{Nitrate}

The cadmium reduction method was employed for nitrate determination. Nitrate was reduced to nitrite when a sample was passed through amalgamated cadmium granules.

\section{Nitrite}

A spectrophotometer equipped with 10 mm cell, adjusted to a wavelength of $540 \mathrm{~nm}$ was used to determine the nitrite concentration of the river water samples.

\section{Phosphates}

A Hach spectrophotometer equipped with $10 \mathrm{~mm}$ cell, adjusted to a wavelength of $575 \mathrm{~nm}$ was used to determine phosphate concentration.

\section{Sulphates}

In the determination of sulphates in the river water samples, sulphate was precipitated as barium sulphate in hot hydrochloric acid medium by addition of barium chloride.

\section{Dissolved oxygen (DO)}

The iodometric method was employed for the determination of dissolved oxygen. A solution of manganous salt was added to the sample followed by sodium hydroxide. The manganese hydroxide revert to a divalent state with liberation of iodine equivalent. The iodine was then titrated with a standard solution of sodium thiosulphate.

\section{Biochemical oxygen demand (BOD)}

The BOD is an empirical test used to estimate the relative oxygen requirements of waste waters, effluents and polluted water bodies. The dilution test was applied skillfully in the BOD determination of the river water samples. The dissolved oxygen content of the river water samples was determined before and after incubation for five days at $20^{\circ} \mathrm{C}$.

\section{Chemical oxygen demand (COD)}

The dichromate method which is the reference method for COD determination was used. The river water samples were boiled under reflux with potassium dichromate and silver sulphate in strong sulfuric acid. Parts of the dichromate was reduced by organic matter and the remainder was titrated with ferrous sulphate. The solution changed from its previous blue-green to reddish brown colour when the end point was reached. 
Microbiological studies

\section{Culture Media and Chemicals}

Mc Conkey agar and lactose sugar were used

\section{Methods}

Each container of the river water sample was shaken properly and $1 \mathrm{ml}$ sample volume was then obtained in a test tube in triplicate. These were diluted appropriately and plated on Mc conkey agar for coliforms determination. The plates were incubated at $37{ }^{\circ} \mathrm{C}$ for 48 hours. All procedures were carried out in an aseptic screen and repeated three times. The total coliforms load was counted and subsequently isolated and confirmed using the lactose sugar test. A positive gas or acid production at the end of incubation period is an indication of the presence of coliforms bacteria.

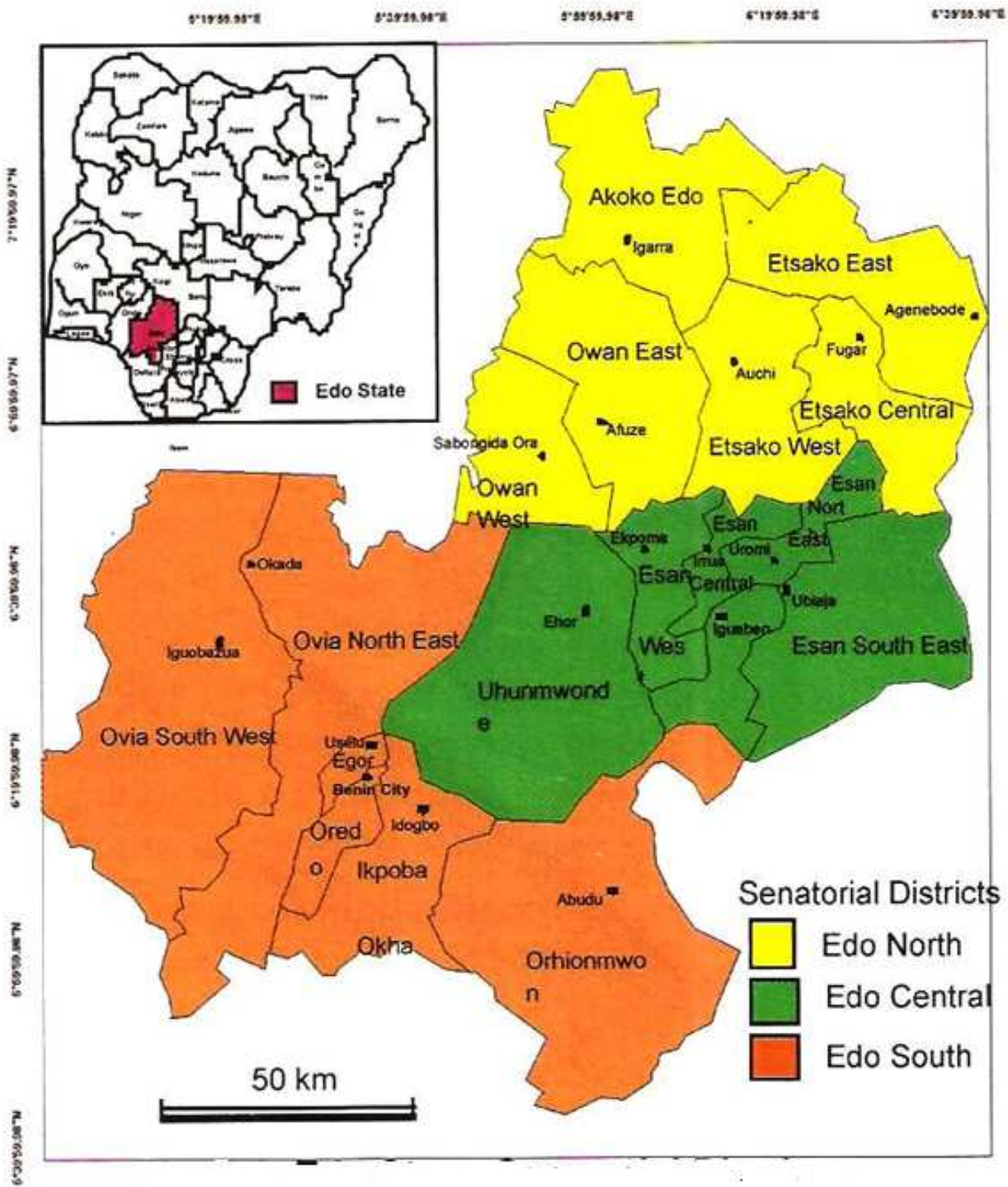

Figure 1: Edo State senatorial zones. 


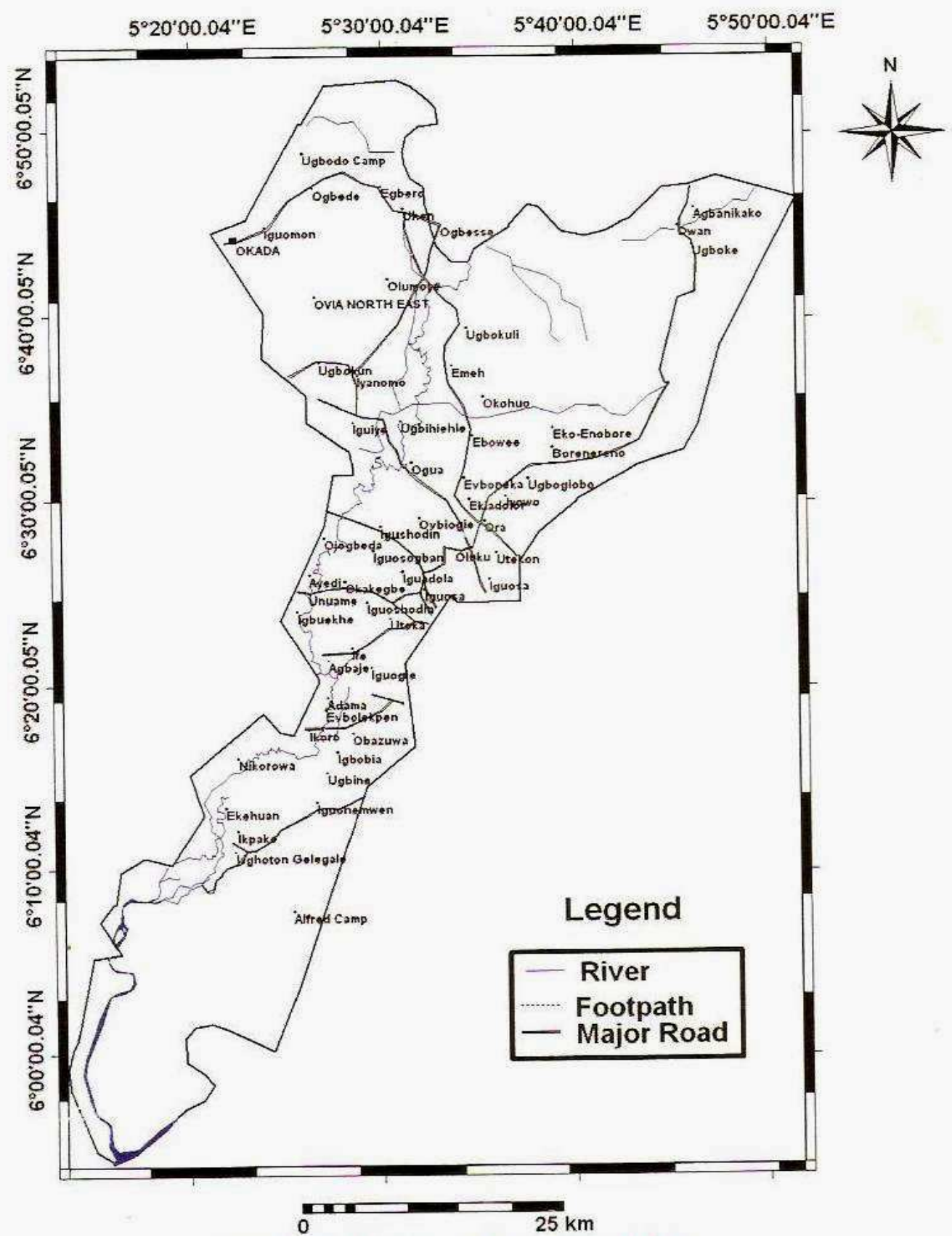

Figure 2: Map of Ovia North-East local government area.

Table 1: The various methods used for metal ion determinations.

\begin{tabular}{lcccccccccccc}
\hline Metal & Al & $\mathbf{C d}$ & $\mathbf{C r}$ & $\mathbf{C u}$ & $\mathbf{F e}$ & $\mathbf{P b}$ & $\mathbf{M n}$ & $\mathbf{H g}$ & $\mathbf{K}$ & $\mathbf{N a}$ & $\mathbf{Z n}$ & As \\
\hline Spect & HACH & AAS & AAS & AAS & HACH & AAS & AAS & AAS & AAS & AAS & AAS & AAS \\
$\lambda(\mathrm{nm})$ & 535 & 228.8 & 357.9 & 24.7 & 510 & 283.3 & 279.5 & 253.7 & 536.9 & 535.6 & 213.9 & 257.9 \\
\hline
\end{tabular}




\section{RESULTS}

Table 2 shows the result of the physicochemical properties and microbiological studies of water samples collected from Ogbese River in Ovia North East L.G.A. of Edo State, Nigeria, in comparison with the recommended limits by three regulatory bodies namely: World Health Organisation (WHO), Federal Ministry of Environment (FMEV), Nigeria and Department of Petroleum Resources (DPR), Nigeria.

The temperature values for the river water fell within the acceptable limit of $27{ }^{\circ} \mathrm{C}-35{ }^{\circ} \mathrm{C}$ for both upstream and downstream regions. The $\mathrm{pH}$ was in the range of $6.70-6.73$ for both upstream and downstream regions. Electrical conductivity was $138-139 \mu \mathrm{S} / \mathrm{cm}$ which is low compared to FMEV limit of $10,000 \mu \mathrm{S} / \mathrm{cm}$. The conductivity of the water samples were due to dissolved ions in them. The range for total suspended solid was $1.33-1.6 \mathrm{mg} / \mathrm{L}$ compared with FMEV limit of $30 \mathrm{mg} / \mathrm{L}$. Ogbese River had a hardness value of 22.43 $\mathrm{mg} / \mathrm{L}$ as against $100 \mathrm{mg} / \mathrm{L}$ limit recommended by WHO. The dissolved oxygen, (DO), a measure of how much the river water samples is saturated with oxygen is in the range of 4.2$4.6 \mathrm{mg} / \mathrm{L}$ which is within the range of $4.0-$ $6.0 \mathrm{mg} / \mathrm{L}$ recommended by DPR, FMEV and WHO. Biological Oxygen Demand (BOD) was in the range of $3.4-4.5 \mathrm{mg} / \mathrm{L}$ compared to WHO limit of 6.0. Chemical Oxygen Demand (COD) was in the range of $39.3-$ $41.5 \mathrm{mg} / \mathrm{L}$ compared to $40 \mathrm{mg} / \mathrm{L}$ limit recommended by WHO. Phosphate concentration was in the range $5.904 \mathrm{mg} / \mathrm{L}$ (upstream) to $23.266 \mathrm{mg} / \mathrm{L}$ (downstream) compared with WHO limit of $0.26 \mathrm{mg} / \mathrm{L}$ which suggests a high concentration of phosphates in the Ogbese River water. Nitrate, nitrite and sulphides were not detected in the water samples. Aluminum and heavy metals such as chromium, cadmium and arsenic were not detected in the river water samples. Even the heavy metals present such as zinc, copper and lead are within WHO recommended limit. Coliform bacterial count values were extremely high ranging from $250,000 \mathrm{cfu} / \mathrm{ml}-$ $2600000 \mathrm{cfu} / \mathrm{ml}$ as against $10 \mathrm{cfu} / 100 \mathrm{ml}$ WHO recommended limit.

Table 2: Result of Physicochemical properties and microbiological studies of Ogbese River Water, Edo State, Nigeria.

\begin{tabular}{|c|c|c|c|c|c|c|c|}
\hline $\mathbf{S} / \mathbf{N}$ & Units & 1 & 2 & $\begin{array}{c}\text { DPR } \\
\text { Limit }\end{array}$ & FMEV & $\begin{array}{c}\text { WHO } \\
\text { limit }\end{array}$ & Method \\
\hline Sample ID & & $1 \mathrm{~A}$ & 1B & & & & \\
\hline Temp. & ${ }^{\circ} \mathrm{C}$ & 27 & 27 & 30 & 35 & 27 & EPA 79 \\
\hline pH & & 6.73 & 6.70 & $6.5-8.5$ & $6.0-9.0$ & $6.5-8.0$ & ASTM D1293-95 \\
\hline EC & $\mu \mathrm{S}$ & 238 & 139 & 10000 & 10000 & N/A & ASTM D1125-95 \\
\hline TSS & $\mathrm{mg} / \mathrm{L}$ & 1.33 & 1.6 & 50 & 30 & N/A & ASTM D1868 \\
\hline TDS & $\mathrm{mg} / \mathrm{L}$ & 71.8 & 72.3 & 2000 & 2000 & 1000 & ASTM D1868 \\
\hline Turbidity & NTU & 5.20 & 5.90 & 15 & 30 & 5 & ASTM D1889-94 \\
\hline Hardness & $\mathrm{mg} / \mathrm{L}$ & 22.43 & 22.43 & & & 100 & ASTM D1126-69B \\
\hline Colour & & $\begin{array}{c}\text { Odourles } \\
\text { s } \\
\end{array}$ & Colourless & & & & \\
\hline Odour & & $\begin{array}{c}\text { Odourles } \\
\mathrm{s}\end{array}$ & Odourless & & & & \\
\hline DO & $\mathrm{mg} / \mathrm{L}$ & 4.2 & 4.6 & $>4.0$ & $>4.0$ & 6.2 & APHA-507 5e \\
\hline BOD & $\mathrm{mg} / \mathrm{L}$ & 3.4 & 4.5 & 125 & 50 & 6 & APHA-507 \\
\hline
\end{tabular}




\begin{tabular}{|c|c|c|c|c|c|c|c|}
\hline COD & $\mathrm{mg} / \mathrm{L}$ & 39.3 & 41.5 & 125 & 40 & 40 & ASTM D1252-95 \\
\hline $\mathrm{HCO}_{3}^{-}$ & $\mathrm{mg} / \mathrm{L}$ & 35 & 42.7 & & & N/A & $\begin{array}{c}\text { ASTM D1067- } \\
92(1996)\end{array}$ \\
\hline $\mathrm{CO}_{3}{ }^{2-}$ & $\mathrm{mg} / \mathrm{L}$ & ND & ND & & & & $\begin{array}{c}\text { ASTM D1067- } \\
92(1996)\end{array}$ \\
\hline $\mathrm{CN}^{-}$ & $\mathrm{mg} / \mathrm{L}$ & $\mathrm{ND}$ & ND & & & & ASTM D3026 \\
\hline $\mathrm{Ca}^{2+}$ & $\mathrm{mg} / \mathrm{L}$ & 5.77 & 4.49 & & & 75 & $\begin{array}{l}\text { ASTM D511- } \\
\text { 93A(1998) }\end{array}$ \\
\hline $\mathbf{M g}^{2+}$ & $\mathrm{mg} / \mathrm{L}$ & 1.86 & 2.62 & & & 50 & $\begin{array}{l}\text { ASTM D511- } \\
\text { 93A(1998) }\end{array}$ \\
\hline $\mathrm{SO}_{4}{ }^{2-}$ & $\mathrm{mg} / \mathrm{L}$ & 0.33 & 0.66 & & & 400 & APHA $427 \mathrm{C}$ \\
\hline $\mathrm{PO}_{4}{ }^{2-}$ & $\mathrm{mg} / \mathrm{L}$ & 5.904 & 23.266 & N/A & N/A & 0.26 & ASTM D515-88 \\
\hline $\mathrm{NO}_{3}^{-}$ & $\mathrm{mg} / \mathrm{L}$ & ND & ND & & & 50 & ASTM D3867 \\
\hline $\mathrm{NO}_{2}^{-}$ & $\mathrm{mg} / \mathrm{L}$ & $\mathrm{ND}$ & ND & & & & ASTM D3867 \\
\hline $\mathbf{S}_{2}^{-}$ & $\mathrm{mg} / \mathrm{L}$ & ND & ND & & & & ASTM $427 \mathrm{C}$ \\
\hline $\mathbf{Z n}$ & $\mathrm{mg} / \mathrm{L}$ & 0.028 & 0.035 & & & 5 & APHA $301 \mathrm{~A}$ \\
\hline $\mathbf{C u}$ & $\mathrm{mg} / \mathrm{L}$ & 0.013 & 0.022 & & & 1 & APHA $301 \mathrm{~A}$ \\
\hline $\mathbf{P b}$ & $\mathrm{mg} / \mathrm{L}$ & 0.009 & 0.01 & & & 0.05 & APHA $301 \mathrm{~A}$ \\
\hline $\mathbf{N i}$ & $\mathrm{mg} / \mathrm{L}$ & 0.003 & 0.004 & & & N/A & APHA $301 \mathrm{~A}$ \\
\hline $\mathbf{C r}$ & $\mathrm{mg} / \mathrm{L}$ & ND & ND & & & 0.05 & ASTM D1687-84(A) \\
\hline Mn & $\mathrm{mg} / \mathrm{L}$ & 0.155 & 0.368 & & & 0.1 & APHA $301 \mathrm{~A}$ \\
\hline $\mathbf{F e}$ & $\mathrm{mg} / \mathrm{L}$ & 0.37 & 0.48 & & & 0.3 & APHA $301 \mathrm{~A}$ \\
\hline Cd & $\mathrm{mg} / \mathrm{L}$ & ND & ND & & & 0.005 & APHA $301 \mathrm{~A}$ \\
\hline As & $\mathrm{mg} / \mathrm{L}$ & ND & ND & & & 0.05 & APHA $301 \mathrm{~A}$ \\
\hline Al & $\mathrm{mg} / \mathrm{L}$ & ND & ND & & & 0.2 & APHA $301 \mathrm{~A}$ \\
\hline $\begin{array}{l}\text { Coliforms } \\
\text { count }\end{array}$ & $\mathrm{cfu} / \mathrm{ml}$ & $2.5 \times 10^{5}$ & $2.6 \times 10^{6}$ & & & $\begin{array}{l}10 \mathrm{cfu} / \\
100 \mathrm{ml}\end{array}$ & EPA-600/8-017,1978 \\
\hline
\end{tabular}

\section{DISCUSSION}

The physicochemical characteristics of the water samples collected from Ogbese River are presented in Table 2. The value obtained for each parameter is the mean of three replicate readings. Two sampling points were chosen separated by a distance of one kilometer. One is upstream and the other downstream.

Temperature measurements are one of the most important factors as the degree of hotness or coldness of the river water body that affects the aquatic organisms (Nicholas, 2005). The temperature of the Ogbese River water samples collected was found to be 27 ${ }^{\circ} \mathrm{C}$ which is within the acceptable range by the
World Health Organisation, (WHO, 2001, 2006). The normal desirable level for temperature as stipulated by the WHO and FMEV (Federal Ministry of Environment) is within the range of $27-35^{\circ} \mathrm{C}$.

The $\mathrm{pH}$ range of the river water samples $(6.70-6.73)$ fell within the acceptable range of $6.0-8.0$ prescribed by DPR, FMEV and WHO although it lies slightly on the acidic side. The river water may however be regarded as being neutral (Fakayode, 2005). The $\mathrm{pH}$ is a very important factor for determining the quality of the river water because it controls the solubility and availability of mineral nutrients and heavy metals to aquatic organisms (Fakayode, 2005). 
Turbidity is a measure of clarity of the river water. The higher the measured TSS and TDS in the water, the higher is the turbidity and the converse is also true. The Ogbese River water is colourless, odourless with slight astringent taste because the values of turbidity (5.20 -5.90 NTU), total suspended solids, TSS (1.33-1.60 mg/L), total dissolved solids, TDS (71.8 - $72.3 \mathrm{mg} / \mathrm{L})$, hardness (22.43 mg/L) and electrical conductivity, EC (138-139 $\mu \mathrm{S})$ are very low and lie within allowable limits recommended by FMEV, DPR and WHO. The slight astringent taste has been attributed to the dissolved ions, especially iron in the river water. The iron concentration in the river water exceeded WHO standard of $0.3 \mathrm{mg} / \mathrm{L}$. The hydrolysis of ferric ion in water affected the $\mathrm{pH}$ making it slightly acidic as indicated by the $\mathrm{pH}$ (Orjiekwe et al., 2006).

Nitrates and nitrite are notorious alga nutrients. The fact that nitrates and nitrite were not detected in the river water samples rules out the possibility of excessive algae growth from sewage and industrial discharges nearby. This observation corroborates with the BOD and COD values which are within allowable limits recommended by FMEV, DPR and WHO. The nitrate level for Ogbese River is in sharp contrast to that observed elsewhere (Ogbeigbu, 2002; Ano et al., 2008; Thomas et al., 2011). According to Ogbeigbu (2002), pollution from organic sources from a brewery plant nearby affected negatively the growth and feeding habits of fishes in Ikpoba River, Benin city. Similarly, Ano et al. (2008) observed that population density, urbanization and industrialization are largely responsible for the high level of nitrate ions in underground water from Abia State which far exceeded the WHO limits. Similarly, Thomas et al. (2011) reported that the high concentration levels for nitrate observed in well water from Eloor industrial area of India which exceeded the WHO guidelines are largely due to pollution from industrial effluents from industries in the area.

Phosphate concentration was in the range $5.904 \mathrm{mg} / \mathrm{L}$ (upstream) and 23.266 $\mathrm{mg} / \mathrm{L}$ (downstream) which are high compared with WHO limit of $0.26 \mathrm{mg} / \mathrm{L}$. The high phosphate values and the disparity between the upstream and downstream values have been attributed to the indiscriminate use of linear alkylbenzene sulphonate-bearing detergents and soaps during laundry and bathing activities witnessed by the river banks (Orjiekwe et al., 2006; Kana, 2004). Sulphate concentration in the river samples tested was low and within allowable limits (Odukoya, 2002).

The heavy metals, chromium, cadmium and arsenic were not detected in the Ogbese river water samples while zinc, copper and lead are present within the allowable limits recommended by WHO for safe drinking water (WHO, 1995). This implies that the river water is free from heavy toxic metals that have been implicated elsewhere in various forms of cancer (Odokun, 2000; Ideriah, 2001; Wang, 2003; Orjiekwe et al., 2006).

Total coliforms bacterial count is utilized as a microbial measure of drinking water quality, largely because they are easy to detect and enumerate in water. The coliforms bacterial count values in the Ogbese river water are extremely high ranging from $2.5 \mathrm{x}$ $10^{5} \mathrm{cfu} / \mathrm{ml}$ for upstream to $2.6 \times 10^{6} \mathrm{cfu} / \mathrm{ml}$ for downstream as against $10 \mathrm{cfu} / 100 \mathrm{ml}$ recommended by WHO for potable water (WHO, 2006). Therefore, the Ogbese River water is not fit for drinking on account of the coliforms bacterial count. Faecal contamination from human, wild animals and runoffs from domestic homes and agricultural farmlands have been ascribed as the source of the coliforms bacteria in the river water (Orjiekwe et al., 2006). Similarly, Nhapi (2001) reported that sewage discharges into Marimba River, Zimbabwe is largely 
responsible for high nitrate level and coliforms bacterial count in the River.

Apart from phosphates, iron and coliforms, most pollution indices measured for Ogbese River water are relatively within the allowable limits compared with our previous study on Evebonede and Ovia Rivers (Orjiekwe et al., 2006)

\section{Conclusion}

The Ogbese River water is not fit as drinking water on account of the coliforms bacterial count and the phosphate content, even though most of the other pollution indices fall within the allowable limits by DPR, FMEV and WHO. This obviously have great health implication for the rural dwellers that depend mostly on the river water for drinking, washing and other domestic uses. The Ogbese River water are to a large extent virtually free from toxic heavy trace metals such as cadmium, arsenic, lead and chromium which are cancerous.

Governments at Federal, State and Local government areas and even Nongovernmental Agencies and International bodies are enjoined to sink functional boreholes for the rural dwellers to discourage them from using the Ogbese River as drinking water. Also, conscious efforts through awareness campaign should be made to educate the local rural dwellers on the scourge and inherent danger of drinking the Ogbese River water.

\section{ACKNOWLEDGEMENTS}

The authors are grateful to the Management of Igbinedion University, Okada for the University Senate Grant to one of us. We are also grateful to Dr Adekunle Oresegun and Mr. Paul Uyimadu, both of Nigerian Institute of Oceanography and Marine Research, Victoria Island, Lagos for their assistance in the bench work.

\section{REFERENCES}

Ano AO, Okwunodulu FU. 2008. Effect of population and level of industrialization on underground water quality of Abia State, Nigeria. African Journal of Biotechnology, 7(4): 439 - 443.

Demirel ZE. 2004. Heavy metal contamination in water and sediments of an estuary in South-Eastern Turkey. International Journal of Environment and Pollution, 21(5): 499 - 510

Fakayode SO. 2005. Impact assessment of industrial effluent on water quality of the receiving Alaro River in Ibadan, Nigeria. Ajeam-Ragee, 10: 1-13

Ideriah JJ. 2001. Heavy metal contamination of soils around municipal solid wastes in Portharcourt, Nigeria. Tanzanian Journal of Sciences, 2(3): 26-28.

Kana TJ. 2004. Levels of nitrate and phosphate in some satellite lakes within Lake Victoria. Tanzanian Journal of Sciences, 3(1): 11-20.

Kumar M, Kumar R. 2013. Assessment of physic-chemical properties of groundwater in granite mining areas in Goramachia, Ilansi, UP, India. International Research Journal of Environmental Sciences 2(1): 19 - 24.

Nhapi IE. 2001. Sewage discharges and nutrient levels in Marimba River. Zimbabwean Journal of Pollution and Public Health, 6(2): 69-75.

Odokun IO. 2000. Seasonal changes in the heavy metals and resistant bacterial population of the new Calabar River, Nigeria. Global Journal of Pure and Applied Sciences, 3(5): 425-439.

Odukoya O. 2002. Chemical composition of wet precipitate in Ibadan. Bulletin of Chemical Society of Ethiopia, 6(2): 141148.

Ogbeigbu AE. 2002. The ecological impact of brewery effluent at the Ikpoba River, Benin City, Nigeria. Journal of Aquatic Sciences, 7(1): 23-35. 
Ogunlaja A, Ogunlaja OO. 2007. Physicochemical analysis of water sources in Ubeji Community and their histological impact on organs of albino mice. Journal of Applied Sciences and Environmental Management, 11: 91 - 94.

Orjiekwe CL, Oshin D, Orjiekwe IU. 2006. Water quality index assessment of Evebonede and Ovia Rivers in Ovia North-East Local Government Area of Edo State, Nigeria. Int. J. Chem., 16(4): 223-228.

Phiri O, Mumba P, Moyo BHZ, Kadewa W. 2005. Assessment of the impact of industrial effluents on water quality of receiving rivers in urban areas of Malawi. Int. J. Environ. Sci. Tech., 2(3): 237 244.

Raccine CH. 2005. White phosphorus poisoning of water foil in an Alaskan salt marsh. Journal of Environmental Science, 2(1): 1-13.
Thomas DR, Sunil B, Latha C. 2011. Physicochemical analysis of well water at Eloor industrial area - seasonal study. Current World Environment, 6: 259 - 264.

Wang HC. 2003. Heavy metal pollution in streams in Zhozhon city in China. Journal of Environmental Health, 1(4):79-87

WHO. 2001. Water Quality Surveys: A guide for the collection and interpretation of water quality data; Studies and Reports in Hydrology N 23, UNESCO/WHO.

WHO. 2006. World Health Organization: Guidelines for drinking water quality; Geneva. Yadav AC, Srivastava VC. 2011. Physico-chemical properties of the water of River Ganga at Ghazipur. Indian J. Sci. Res., 2(4): 41-44. 